\title{
Towards Improved Protection of Vulnerable Road Users
}

\author{
L. Hynčík* \& H. Čechová \\ New Technology - Research Centre in the West Bohemia Region, University of West Bohemia, Plzeñ, Czech \\ Republic, \\ *Corresponding author: hyncik@ntc.zcu.cz
}

J. Maňas

MECAS ESI s.r.o., Plzen̆, Czech Republic

J. Kovanda

Faculty of Transportation Sciences, Czech University of Technology, Prague, Czech Republic

DOI: 10.2478/V10158-011-0001-0

\begin{abstract}
The paper aims at reducing injury risk and an overall increase in pedestrian passive safety by proposing pedestrian friendly vehicle design. Statistical data are used to identify the most vulnerable population group also regarding the economic losses caused by deaths or medical treatment. An age dependent anthropometric approach enables the development of specific virtual pedestrian biomechanical human body models. The developed virtual pedestrian models are explored to analyse the influence of vehicles in pedestrian impact on injury risk caused by a vehicle industrial demonstrator using numerical simulation. The analysed injury criteria serve for a comparison of vehicle frontal part design variants.
\end{abstract}

KEY WORDS: Vulnerable road user, anthropology, safety, simulation, optimization.

\section{INTRODUCTION}

Traffic accidents are within a group of external consequences causing the third highest number of deaths in the Czech Republic, just after deaths caused by falls and suicides (Czech Statistical Office, 2007). The numbers of deaths or fatally injured citizens prove that traffic accidents and their consequences are still a serious problem to be solved. The statistics show that the number of accidents has been decreasing slowly in the past years (Skácal, 2007 and the Ministry of Transport of the Czech Republic, 2010). However, the decrease needs to be sped up regarding also the socioeconomic aspects of the problem (Daňková, 2007).

Traffic accidents cause either physical losses, such as death, fatal injuries and physical damage, or also psychological traumas. Traffic accidents' consequences are carried, not only by the government, but also by the state budget, due to production losses, widow and orphan allowances and disability pensions. Traffic accidents account for more than 1,300 deaths, 6,000 fatally injured and the society losses costing over 49 billion CZK in the Czech Republic yearly (Daňková, 2007). Such a negative trend necessitates urgent actions to be taken in order to change the situation. 


\section{MOTIVATION}

A lot of effort is devoted to both passive and active safety systems development, where virtual human body models start to play significant role, since they become powerful tool for supporting the development of human-friendly and safe vehicles through a numerical method using computer simulation.

The body stature, gender and age play a considerable role within the traffic accident. This means that several groups of people suffer higher injury risk due to traffic accidents. These groups are mainly children and elderly people.

Consequently, it is necessary to develop and validate correct biofidelic models (Haug, 2004). Based on the injury description implemented in the virtual human model, they might predict the human body response just by computational time. Hence, a lot of structural designs, technical solutions, and impact scenarios might be analysed before getting into experimental development and further production. The virtual human models contribute not only to the safety systems development, but the virtual prototyping as a complex development approach also reduces the production process costs and contributes to the protection of the living environment.

\section{METHOD}

The problem investigated in the paper and the presented results are based on the results of the research project CG911-044-150 "Reduction of accidents consequences of vulnerable road users in Czech population" supported by the Ministry of Transport of the Czech Republic within the years $2008-2010$. The aim of the project was to increase the passive safety of vulnerable road users and reduce injury risk by the new design and construction of passive safety devices using numerical simulation. Existing software enabling the anthropometrical scaling of the basic male, female, and child models depending on an age from 6 to 55 years was extended by child anthropometrical data under 6 years, elderly anthropometrical data over 55 years, and further biomechanical data over the population. The developed virtual biomechanical models of vulnerable road users were used to analyse the influence of vehicles in pedestrian impacts in injury risk using industrial demonstrators. Based on injury mechanisms analysis, new structural designs of the vehicle front end which reduced the injury risk of vulnerable road users were proposed and analysed.

The paper focuses on the territory of the Czech Republic and the main task is to reduce accidents consequences of vulnerable road users in the Czech population. The paper describes the identification of the most vulnerable group within the vulnerable road users regarding gender, age, and typical accident. The research also takes into account the socioeconomic aspects of the traffic accident including a vulnerable road user. The algorithm scaling a virtual human body model to the identified specimen is then presented and the identified accident is provided by numerical simulation. A simple process to develop structural changes to the impacting vehicle is applied, and the numerical simulation using the optimized vehicle is reproduced to propose technical improvements leading to a decrease in the injury criteria values and so reducing the accidents consequences of the vulnerable road user.

\subsection{Identification}

The accident analysis and the related socioeconomic costs identification come from the yearly reports issued by the police (Tesařík and Sobotka, 2008), BESIP (2008), data and scientific papers by the Transport Research Centre (Skácal, 2007), the Ministry of Transport 
of the Czech Republic (2010), and mainly statistical data of the Czech Statistical Office (2007). The aim of the identification was to:

- Identify the most injured group of vulnerable road users;

- Summarize the related socioeconomic costs.

Based on the above-mentioned project investigation (Hynčík et al., 2011), the most injured road users were identified in the following groups:

- Citizens between 20 and 24 years old, between 50 and 54 years old and older than 75 years;

- Pedestrians as belonging to most injured road users;

- Males as having a higher death percentage than females.

The studies summarizing the socioeconomic costs directly related to the age of the injured citizen are currently missing. Hence the following statements flow from the generally available data. From the socioeconomic point of view, the highest losses are related to the citizen's death, fatal injuries, or production losses. The production losses take into account the GDP (gross domestic product) coming from the number of citizens of productive age (males from 15 till 62 years old, females from 15 till 60 years old).

The available data summarized by Hynčík et al. (2011) prove that the socioeconomic costs related to the death exceed twice the costs related to the fatal injuries and greatly exceed the costs related to minor injuries or physical damage.

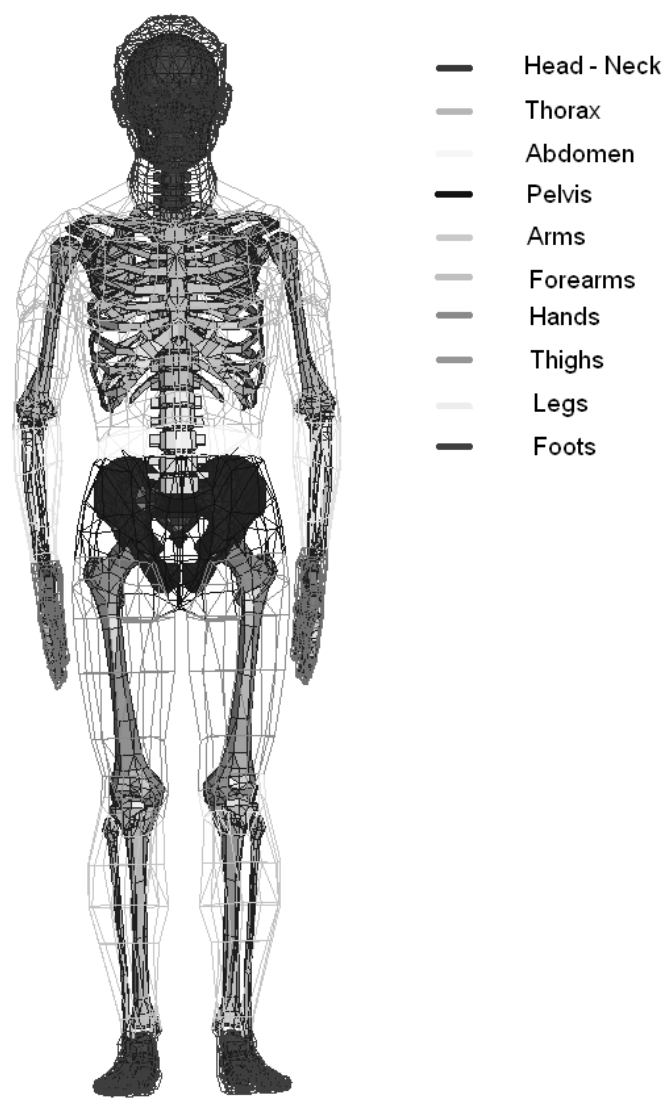

Figure 1: Human articulated rigid body model. 
The major part of the socioeconomic costs is shaped by indirect costs which include the production losses and the related social expenses. The indirect costs are just as low as the severity of the traffic accident. The direct and indirect costs are not so different except in the case of death. The indirect costs are even higher than the direct costs with minor injuries.

From the socioeconomic point of view, the most unfavourable traffic accidents are those including the death of a citizen at a productive age. Hence the main task is to eliminate fatal traffic accidents where the productive age citizens participate. Taking into account the existing safety systems development for the average population, and based on the above socioeconomic costs identification, the following group of vulnerable road users is taken for further investigation:

- Male pedestrian aged between 50 and 54 years (with an average of 52 years old);

- Municipal area passenger car impact at a speed of $50 \mathrm{~km} / \mathrm{h}$.

3 percentiles (5\%-tile, 50\%-tile and 95\%-tile) based models aged 52 years are developed by scaling the original model and the passenger car's impact is numerically simulated. Several structural changes to the car's front end are proposed and the pedestrian injuries are analysed according to this optimization.

\subsection{Modelling}

The current experimental development of safety systems use the standardized dummies that are fully tuned for the specific impact description. However, they are not completely biofidelic and furthermore, they represent only a limited set from the population.

The basic model used for investigation is the 50\%-tile male model called Robby, developed by Hynčík (2001). The model consists of rigid bodies separated into segments connected by biomechanical joints (Robbins, 1983). The model also contains all main skeletal muscles implemented (see Figure 1) and injury criteria (Schmitt et al. 2004 and Cichos et al., 2006).
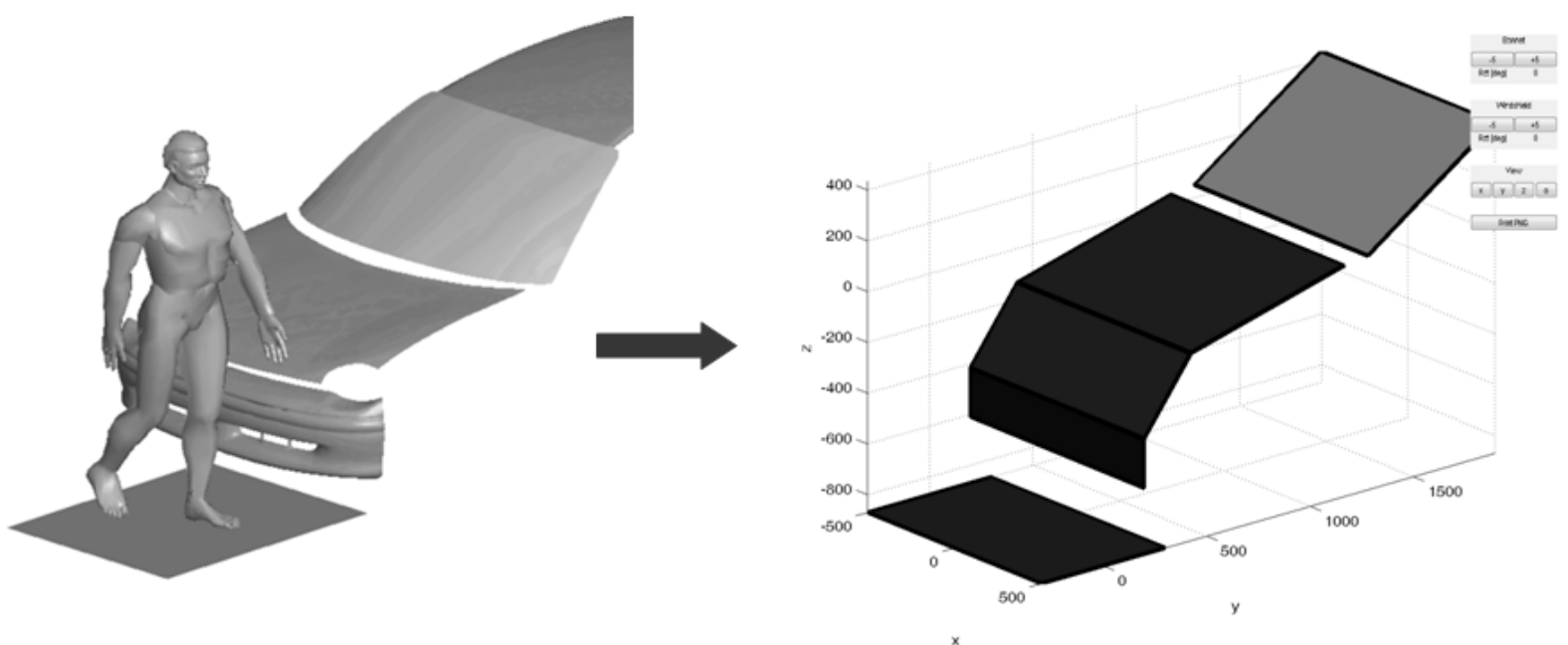

Figure 2: Pedestrian impact position: car demonstrator (left) and simplified model (right). 
However, everyone is different from an anthropometry point of view and the separation of the overall human body population into categories such as 5\%-tile, 50\%-tile and 95\%-tile (not age dependent) is not enough from an application point of view. Moreover, the development of a particular human body model for any population specimen is not possible.

Hence, based on a wide literature review, a scaling algorithm has been previously developed (Hynčík et al., 2007). The algorithm scales a reference model separated into segments connected by joints, updating its major anthropological dimensions and dynamical properties. The update of the algorithm is done by adding additional anthropometrical data (Bláha et al., 1985) and scaling joint flexibility based on age (Araújo, 2008).

Based on the scaling algorithm and the above identified accident scenario, a 52 year old pedestrian model is developed for further investigation. Since the anthropometric data implemented in the scaling algorithm contains various population percentages, 3 models (5\%-tile, 50\%-tile and 95\%-tile ones) are developed for numerical analysis and comparison. The models are further referred to as p05a52, p50a52 and p95a52.

\subsection{Impact simulation}

As identified in section 3.1, the most vulnerable road user is a male pedestrian aged between 50 and 54 years in a municipal area in an impact with a passenger car at the speed of $50 \mathrm{~km} / \mathrm{h}$. In order to have a reference scenario for comparison, a similar accident described by Kerrigan (2005) is taken into account as a reference one.

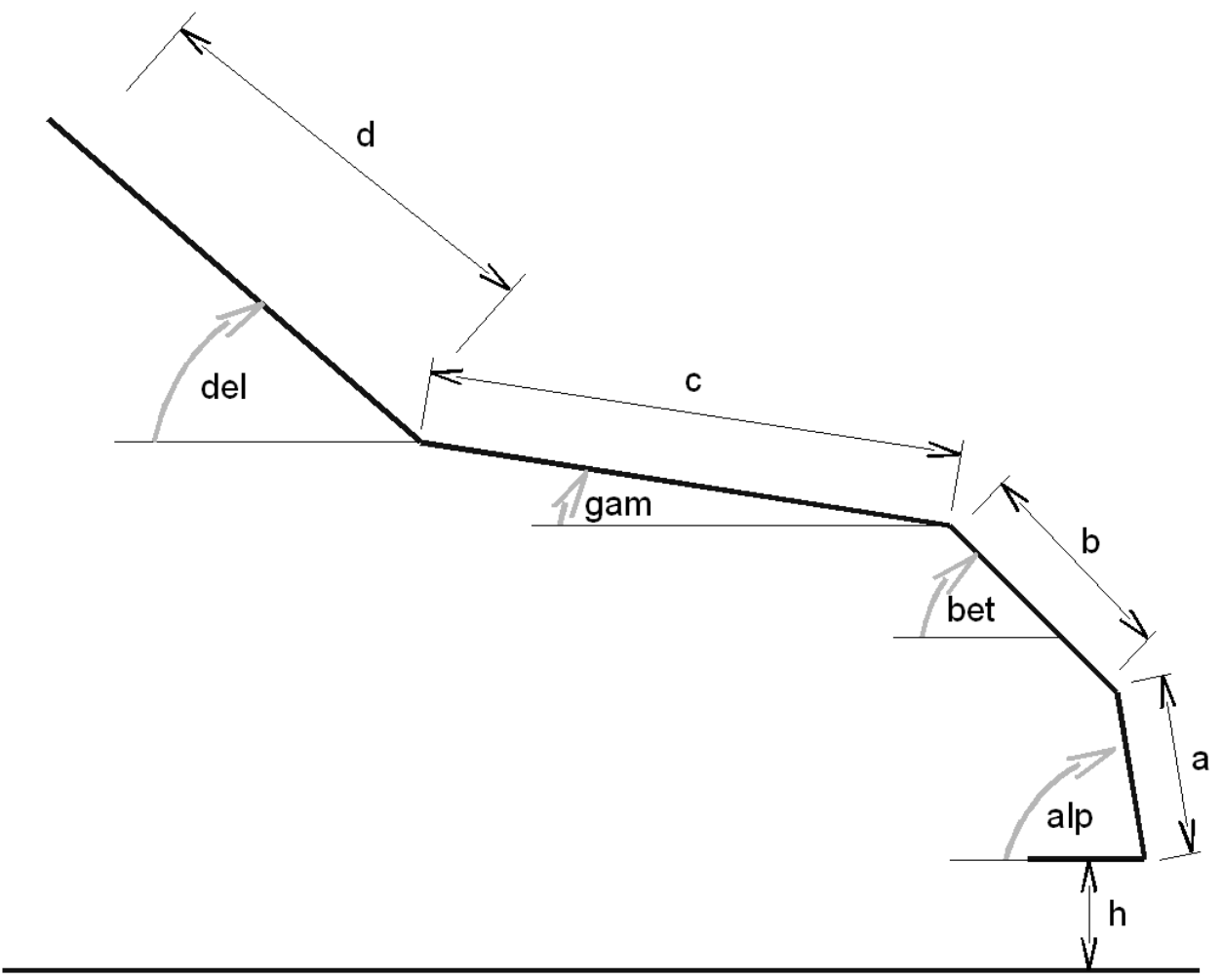

Figure 3: Parametric vehicle front end design. 
The standard available car model is taken as a demonstrator (see Figure 2 left). In order to have a simple model description for further optimization, the model is simplified (see Figure 2 right) and parameterized, as shown in Figure 3.

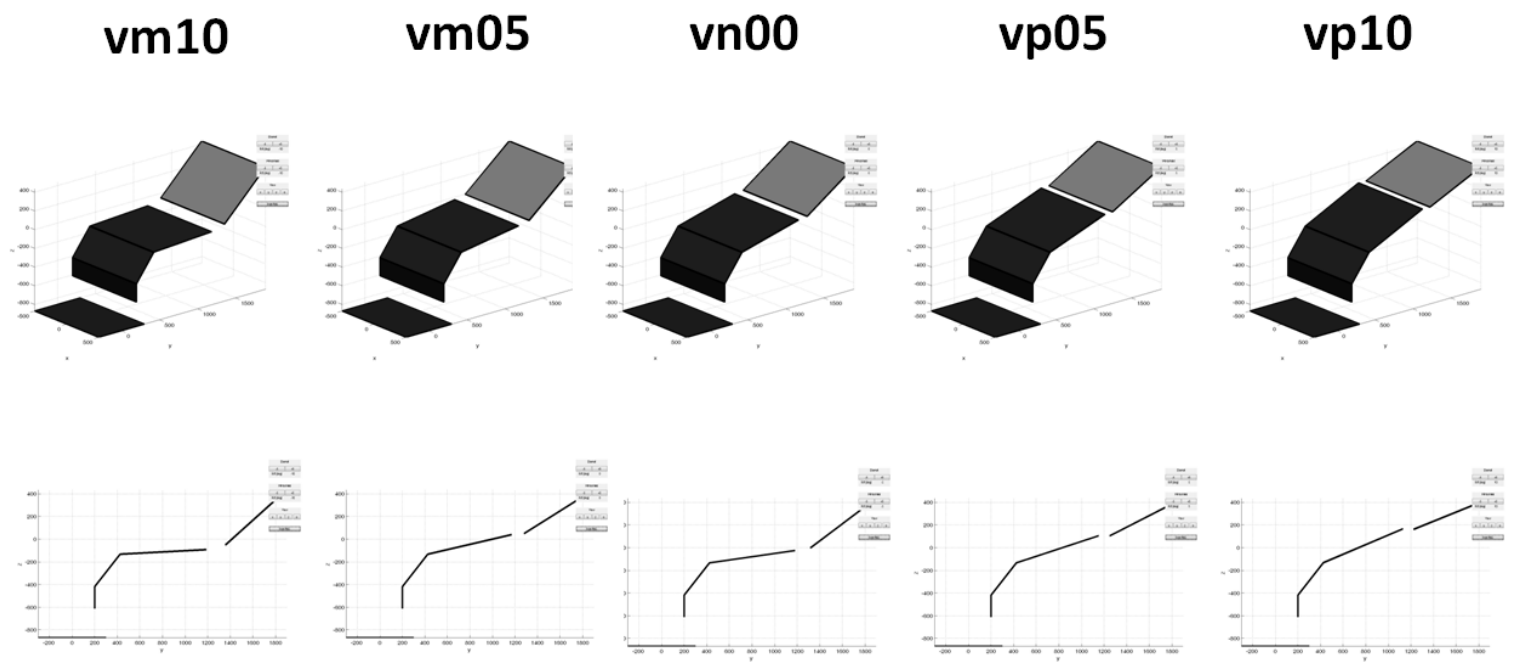

Figure 4: Optimization of vehicle front end design.

The contact between the car and the pedestrian is the crucial thing to be implemented in such simulations. Correct contact modelling in rigid body based approach to biomechanics is crucial due to the high deformation of biological materials. The energy absorption must be implemented in the internal contact variables due to the rigidity of the contacting bodies. Kerrigan (2005) describes the contact response between a human body and a particular car part (bumper, bonnet, and windshield) that are necessary input data after positioning the human model to the impact position (see Figure 2).

Table 1: Car front end optimization.

\begin{tabular}{|c|c|c|c|c|c|}
\hline Variant & $v m 10$ & $v m 05$ & $v n 00$ & $v p 05$ & $v p 10$ \\
\hline Bonnet angle & $-10^{\circ}$ & $-5^{0}$ & \multirow{2}{*}{ Original model } & $+5^{\circ}$ & $+10^{\circ}$ \\
\hline Windshield angle & $-10^{\circ}$ & $-5^{\circ}$ & & $+5^{\circ}$ & $+10^{\circ}$ \\
\hline
\end{tabular}

The basic model has been validated firstly for the standard impact conditions (Kerrigan, 2005) and then several variants of the car front end structural design (see Figure 4) have been developed for analysis of its influence on injuries caused by pedestrian impact. The original car model is referred as $v n 00$. Additional variants $v m 10, v m 05, v p 05$ and $v p 10$ are developed (see Figure 4) so that both the bonnet and the windshield are rotated by 5 or 10 degrees in both negative and positive senses relative to their original positions. The analysis is in line with Regulation EC No. 78/2009 on vehicles parameters evaluation. 


\section{RESULTS}

Numerical simulations of the pedestrian impact with all the developed car front end variants and 52 year old 5\%-tile, 50\%-tile and 95\%-tile human models are developed. The results of the simulations show the injury probability dependence on the car front end structural design.

Table 2: Human percentile and front end design dependent head injury criterion.

\begin{tabular}{|c|c|c|c|c|c|}
\hline \multirow{2}{*}{ Variant } & \multicolumn{5}{|c|}{ HIC } \\
\cline { 2 - 6 } & $v m 10$ & $v m 05$ & $v n 00$ & $v p 05$ & $v p 10$ \\
\hline p05a52 & 8562 & 8739 & 3912 & 2311 & 1684 \\
\hline p50a52 & 4365 & 2620 & 1901 & 1517 & 1227 \\
\hline p95a52 & 2449 & 1847 & 1389 & 1173 & 1018 \\
\hline
\end{tabular}

Table 3: Human percentile and front end design dependent 3ms criterion.

\begin{tabular}{|l|r|r|r|r|r|}
\hline \multirow{2}{*}{ Variant } & \multicolumn{5}{|c|}{$3 m s$} \\
\cline { 2 - 6 } & $v m 10$ & $v m 05$ & $v n 00$ & $v p 05$ & \multicolumn{1}{c|}{$v p 10$} \\
\hline p05a52 & 69 & 69 & 65 & 65 & 65 \\
\hline$p 50 a 52$ & 57 & 57 & 62 & 54 & 50 \\
\hline$p 95 a 52$ & 43 & 40 & 46 & 38 & 39 \\
\hline
\end{tabular}

Concerning the pedestrian impact, the head injury criterion $(H I C)$ and the thorax injury criterion $(3 \mathrm{~ms})$ criterion are analysed for 3 pedestrian percentiles and 5 car front end structural design including the original one. Table 2 shows the head injury criterion dependence on the car front end structural design for all 3 analysed pedestrian percentiles, whilst

Table 3Table 3 shows the thorax injury criterion dependence on the car front end structural design for all 3 analysed pedestrian percentiles. Both the head injury criterion and the thorax injury criterion are also illustrated on the bar graphs in Figure 5 and Figure 6.

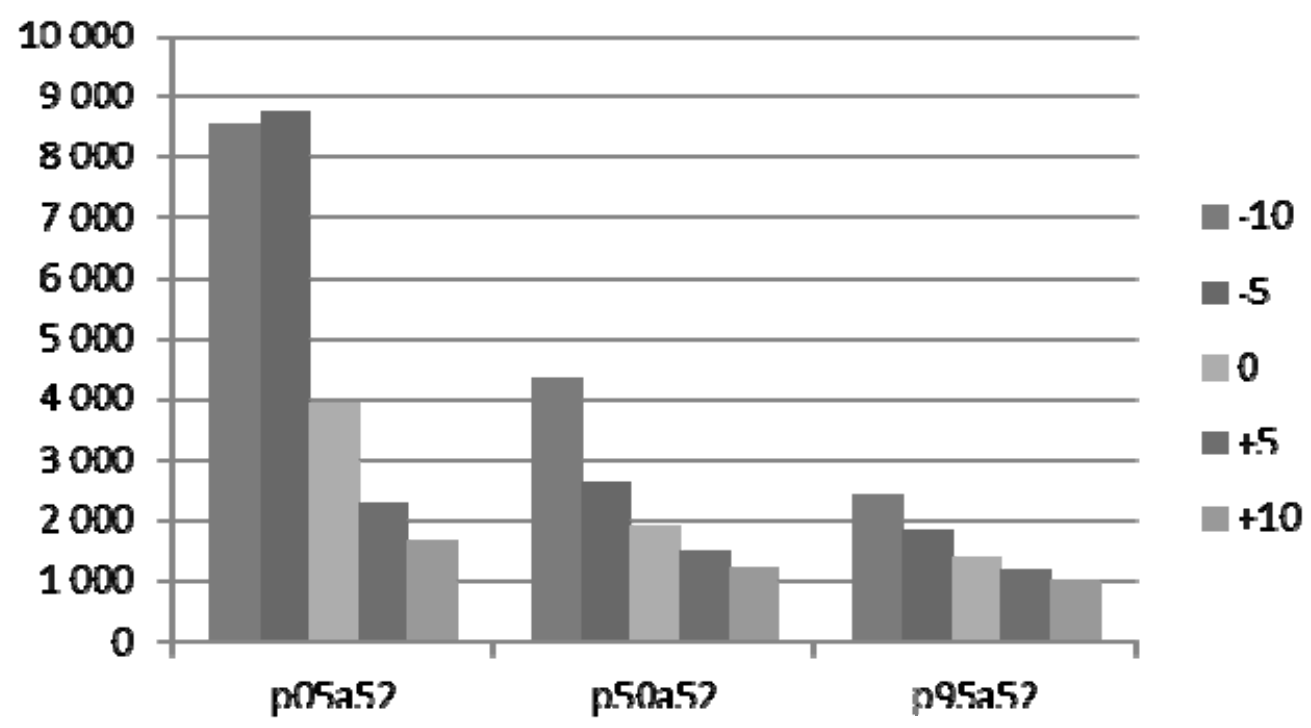

Figure 5: Human percentile and front end design dependent HIC. 


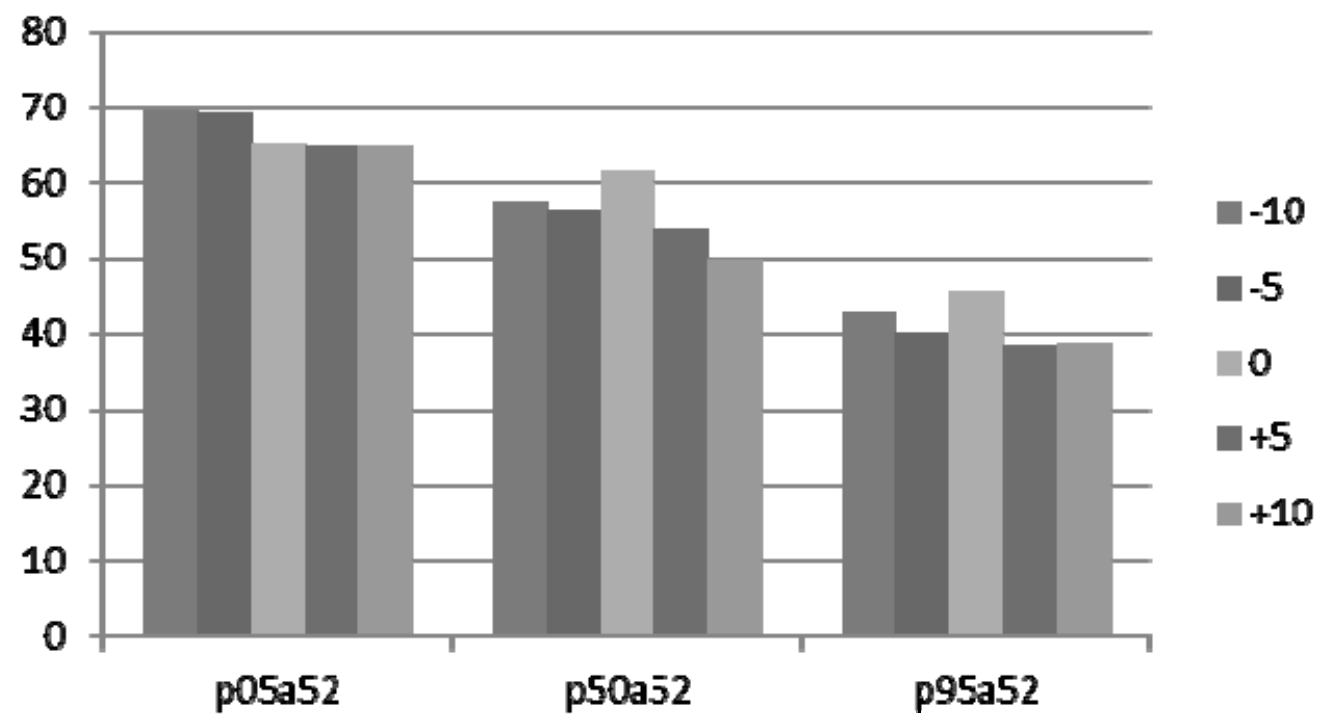

Figure 6: Human percentile and front end design dependent $3 m s$.

\section{DISCUSSION}

The bar graphs in Figure 5 and

Figure 6 show a significant influence of the car front end structural design on pedestrian injuries. Furthermore, the results prove that different people according to their body status suffer very different injuries, measured by the injury criteria. Based on the graphs, it can be stated with minor deviations, that the lower angle between the bonnet and the windshield causes lower injuries on the head and the thorax. Whilst the thorax injury criterion is under the limit for all cases (Schmitt, 2004), the head injury criterion considerably decreases by flattening the angle between the bonnet and the windshield.

\section{CONCLUSION}

The paper contributes to increasing the passive safety of vulnerable road users and to reducing injury risk by analysing the car front end structure using numerical simulation. Virtual biomechanical models of vulnerable road users developed by scaling were used to analyse the influence of a vehicle's structural design on injury risk using a demonstrators. Based on the injury mechanisms analysis, the car front end shape design was analysed for vulnerable road users.

\section{ACKNOWLEDGMENT}

The work is supported by the project CG911-044-150 of the Czech Ministry of Transport and by the John H. and Amy Bowles Lawrence Foundation. Great thanks belong to ESI Group International. 


\section{REFERENCES}

Araújo, C. G., 2008. Flexibility assessment: normative values for flexitest from 5 to 91 years of age. Arq. Bras. Cardiol, Vol. 90, pp. 257-263.

BESIP, 2008. Revize a aktualizace Národní strategie bezpečnosti silničního provozu na období 2008 - 2010 (2012). http://www.ibesip.cz

Bláha, P. et al., 1985. Antropometrie Československé populace od 6 do 55 let, Československá spartakiáda.

Cichos, D., de Vogel, D., Otto, M., Schaar, O., Zölsch, S., 2006. Crash Analysis Criteria Description.

Český statistický úřad, 2007. Vnější prř́činy úmrtí v ČR v letech 1994 až 2006. http://www.zlin.czso.cz/csu/2007edicniplan.nsf/itisk/AE00312050

Daňková, A., 2007. Ekonomická stránka dopravnich nehod. Dopravní inženýrství, vol. 2. http://www.dopravniinzenyrstvi.cz/clanky/ekonomicka-stranka-dopravnich-nehod.

Hynčík L., 2001. Rigid Body Based Human Model for Crash Test Purposes. Engineering Mechanics, Engineering Academy of the Czech Republic, vol. 8, issue 5, pp. 1-6.

Hynčík, L., Kováŕ, L., Kovanda, J. et al., 2011. Zvyšování pasivní bezpečnosti zranitelných účastníků dopravy. Zpráva $\mathrm{k}$ řešení aktivity A002 dílčího cíle DC05 projektu Ministerstva dopravy č. CG911-044-150. Západočeská univerzita v Plzni.

Hynčík, L., Nováček, V., Bláha, P., Chvojka, O., Krejčí, P., 2007. On scaling of human body models. Applied and Computational Mechanics, University of West Bohemia, Pilsen, Vol. 1, No.1, pp. 63-74.

Kerrigan, J. R., Murphy, D. B., Drinkwater, D.C., Kam, C.Y., Bose, D., Crandall, J.R., 2005. Kinematic corridors for PMHS tested in full-scale pedestrian impact. University of Virginia Center for Applied Boimechanics. Paper No. 05-0394.

Ministerstvo dopravy, 2010. Statistiky nehodovosti. http://www.mvcr.cz/clanek/statistiky-dopravnich-nehod-informace-o-nehodovosti-vceske-republice.aspx

Regulation EC No. 78/2009 of the European Parliament and of the Council of 14 January 2009 on the type-approval of motor vehicles with regard to the protection of pedestrians and other vulnerable road users, amending Directive 2007/46/EC and repealing Directives 2003/102/EC and 2005/66/EC

Robbins, D. H., 1983. Anthropometric Specifications for Mid-Sized Male Dummy, Volume 2. University of Michigan Transportation Research Institute (UMTRI), research report number UMTRI-83-53-2.

Schmitt, K. U., Niederer, P., Walz, F., 2004. Trauma Biomechanics, Introduction to Accidental Injury. Springer-Verlag, Germany. 
Skácal, L. 2007. Hloubková analýza mezinárodního srovnání dopravní nehodovosti v $\check{C} R$. http://www.czrso.cz/index.php?id=402

Tesařík, J., Sobotka, P., 2008. Informace o nehodovosti na pozemních komunikacích České republiky za rok 2008. Policie ČR.

http://aplikace.mvcr.cz/archiv2008/statistiky/nehody.html 